\title{
ICE-CORE ANALYSIS AT SITE A, GREENLAND: PRELIMINARY RESULTS
}

\author{
by
}

\author{
R.B. Alley
}

(Geophysical and Polar Research Center, University of Wisconsin, 1215 W. Dayton Street, Madison, WI 53706-1692, U.S.A.)

and

B.R. Koci

(Polar Ice Coring Office, University of Nebraska-Lincoln, 1320 Q Street, Lincoln, NE 68588, U.S.A.)

\section{ABSTRACT}

Ice-core drilling at Site A, Greenland $\left(70^{\circ} 45^{\prime} \mathrm{N}\right.$, $35^{\circ} 57.5^{\prime} \mathrm{W}$; $3145 \mathrm{~m}$ a.s.l.) by the Polar Ice Coring Office recovered two cores of about $100 \mathrm{~m}$ each, which are now in storage awaiting further analysis. Field studies show that visible strata in the cores record both individual storms and individual years; a typical year comprises 15 storm deposits. Pore close-off occurs between 75 and $80 \mathrm{~m}$ depth. The grain-growth rate in isothermal firn and ice is about $7.8 \times 10^{-3} \mathrm{~mm}^{2} \mathrm{a}^{-1}$, the $10 \mathrm{~m}$ temperature is about $-29.5^{\circ} \mathrm{C}$, and the accumulation rate over the last 200 years is about $290 \mathrm{~mm} \mathrm{a}^{-1}$ ice. Melt events occur about once every 40 years, and major events can be correlated between cores separated by $20 \mathrm{~m}$.

\section{INTRODUCTION}

As part of the site-selection activities for the proposed Greenland Ice Sheet Program (GISP) II deep drilling (Committee for Science Planning in Greenland 1985), personnel from the Polar Ice Coring Office (PICO) drilled two $100 \mathrm{~mm}$ diameter cores at Site A, near Crête, Greenland, during June and July 1985. Site A is located at lat. $70^{\circ} 45^{\prime} \mathrm{N}$, long. $35^{\circ} 57.5^{\prime} \mathrm{W}$, and $3145 \mathrm{~m}$ a.s.l. (personal

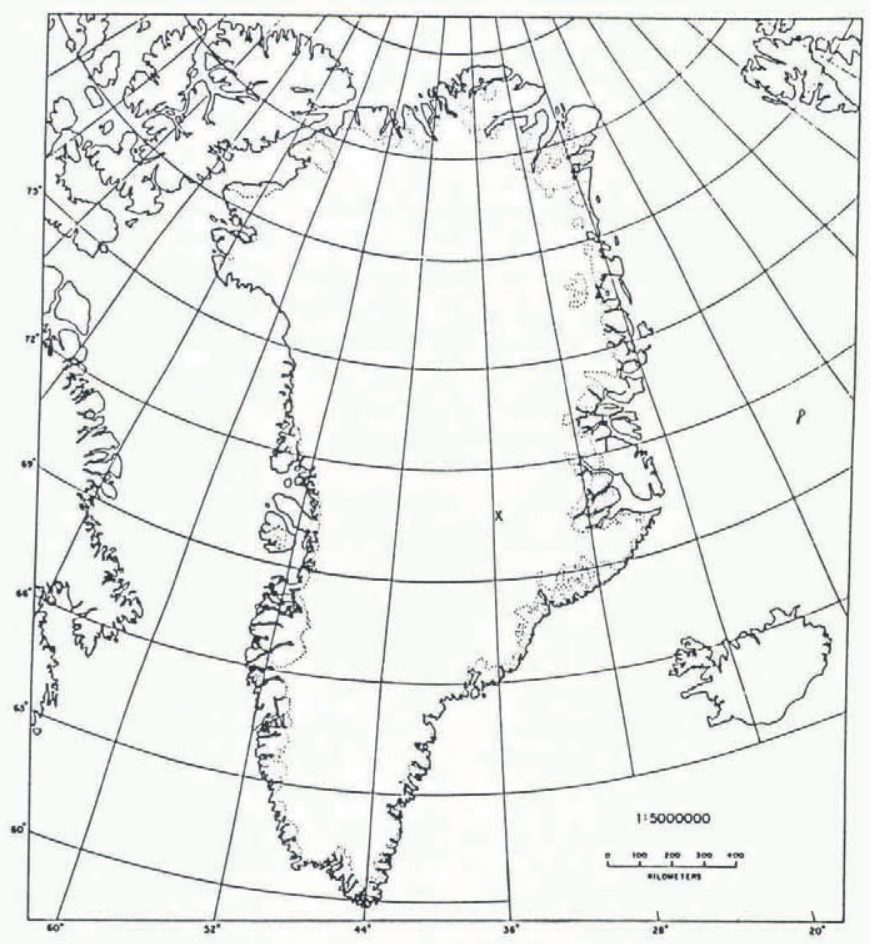

Fig.1. Location map of Greenland; $(x)$ indicates Site A. communication from J.F. Bolzan, 1986; Fig.1). The cores were $95.5 \mathrm{~m}$ and $109.1 \mathrm{~m}$ long and core recovery exceeded $99 \%$. Quality was good on the shorter core and excellent on the longer. These cores are now in storage at the State University of New York at Buffalo. Here we report on the data collected in the field during core drilling and logging.

\section{METHODS}

Core was collected using the electro-mechanical PICO 4 in drill and the PICO $100 \mathrm{~m}$ winch (with a maximum depth capability of $200 \mathrm{~m}$ ). Core in its as-drilled condition was logged on a light-table for visible stratification and evidence of melt. Densities were computed from measurements of the length, diameter, and mass of core samples. Chips were taken from the side of the core and cut into thin sections within $0-48 \mathrm{~h}$ of coring. Core was then sealed in polyethylene tubing and stored in insulated boxes. All core processing was conducted in a pit at temperatures below $-10^{\circ} \mathrm{C}$, and care was taken at all steps to minimize contamination of the core for future studies.

Samples for sectioning were first saturated with supercooled dimethyl phthalate (Perla 1982) and frozen. A microtome was then used to remove from one side a thickness greater than one-grain diameter; that side was then attached to a labeled glass slide with a rapid-curing, ethyl-based cyanoacrylate adhesive (Daley and Kirby 1984; we used Pacer Tech E-5, Campbell, California). Curing of the adhesive took about $12 \mathrm{~h}$, and was conducted on a metallic heat sink in order to avoid heat build-up during the exothermic hardening. Sections were then reduced to about a half-grain diameter using a hand-held microtome knife, a technique that produced good sections $100 \%$ of the time. Sections were photographed in transmitted, cross-polarized light (to delineate grain boundaries) and in reflected light (to obtain truly two-dimensional surfaces for stereologic analysis). Contrast between ice and filler was enhanced by coloring the surface with an indelible marker, which soaks into the filler but beads off the ice (personal communication from K. Beatley, 1984). Methods and errors are discussed further in Alley (unpublished).

In addition to the core studies, we mapped one $2 \mathrm{~m}$ pit. We also monitored surface-accumulation stakes and observed surface conditions during the field season.

\section{RESULTS}

Pit studies

Our surface and pit studies show that visible strata are produced by individual storms (see also Benson 1962 and Hammer 1985). During our field season, a strong windstorm with significant snowfall deposited a dense, fine-grained wind slab about $50 \mathrm{~mm}$ thick. This was followed by a period of clear, still weather, during which $10-20 \mathrm{~mm}$ of 


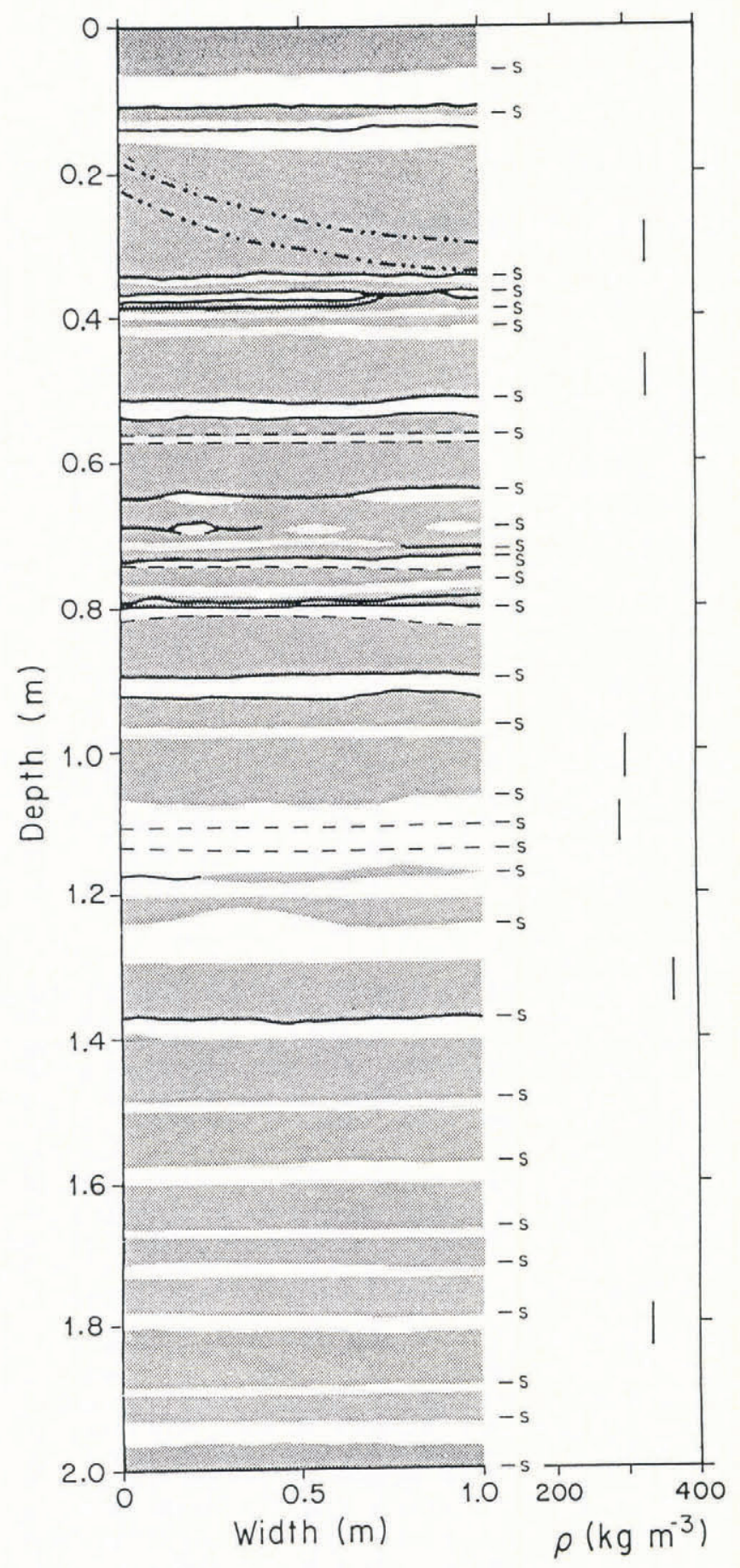

Fig.2. Pit map from Site A. Fine-grained firn is patterned, coarse-grained firn is white, crusts are shown by solid lines, indistinct crusts are shown by dashed lines, and cross-beds in sastrugi are shown by dot-dash lines. Bases of individual storms are labeled $-s$, and density, $\rho$, is shown.

surface hoar was deposited, and then by accumulation of about $10 \mathrm{~mm}$ of snow during a still-air snowfall. A second storm then deposited a $40 \mathrm{~mm}$ thick wind slab of density $400-450 \mathrm{~kg} \mathrm{~m}^{-3}$. In some places most or all of the low-density material was removed by wind erosion during this second storm, but in other places almost the entire thickness was preserved between the wind slabs.

Examination of the pit (Fig.2) shows the same pattern repeated over the $2 \mathrm{~m}$ exposed. (The uppermost layer in Figure 2 was deposited by the first windstorm described above.) Storm deposits are the dense, fine-grained layers, often resting on crusts and sometimes showing cross-bedding. The base of each wind slab is indicated in Figure 2. Each wind slab is overlain by coarser-grained,

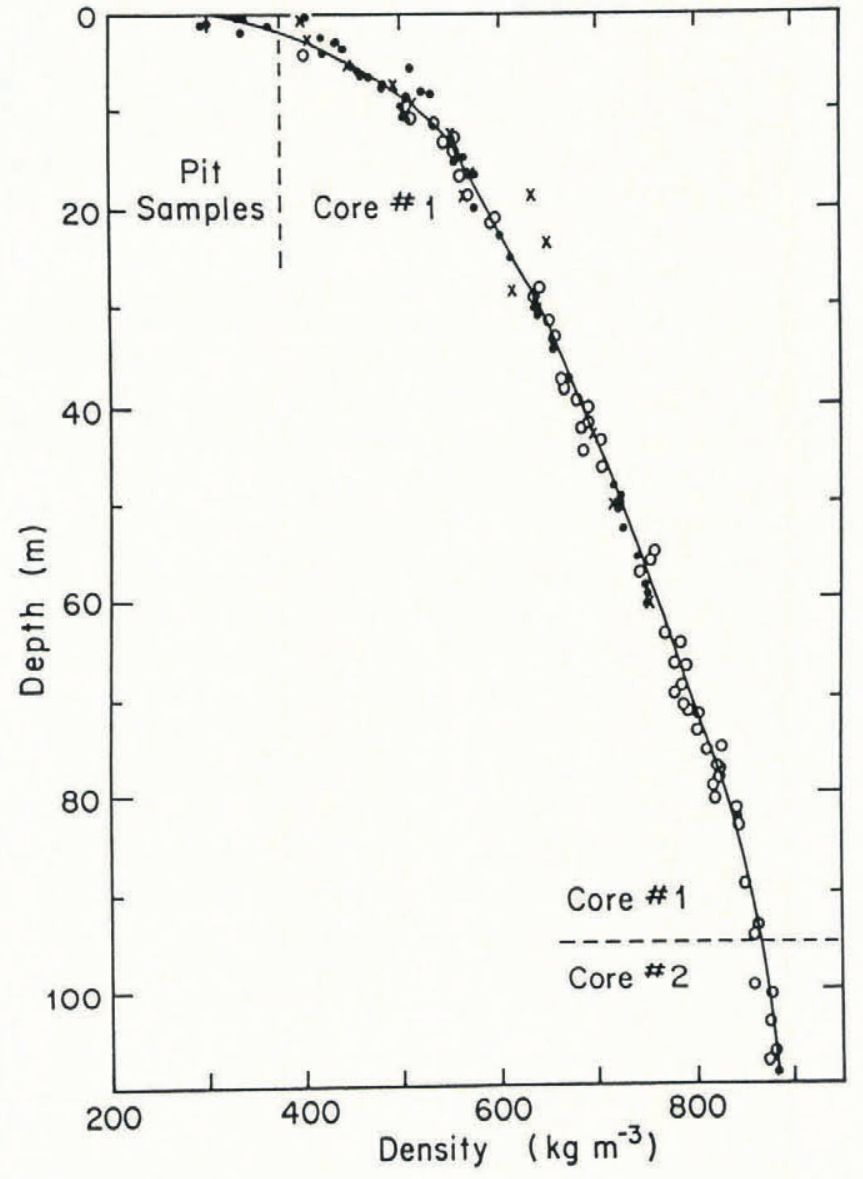

Fig.3. Depth-density profile. Pit samples were measured with density tubes; samples from cores 1 and 2 are indicated. Solid circles (•) indicate the most accurate volume-mass measurements, open circles (o) indicate greater uncertainty in determining volume, and crosses $(x)$ indicate point-count densities from thin sections. The smoothed curve was drawn by inspection.

lower-density material that of ten shows crystal-growth facets and thus is depth hoar. The contact between fine and coarse firn can be gradational or abrupt. An annual signal is indicated by a variation in the proportion of fine-grained and coarse-grained firn; what we interpret as late-summer / autumn is marked by a predominance of coarse firn (see also Benson 1962). Such a layer, interpreted as late-summer 1984 , occurs at about $1.1 \mathrm{~m}$ in Figure 2. The storm deposits near $1.1 \mathrm{~m}$ depth are medium-grained at the base and grade upwards to depth hoar; in a subsequent paper (Alley, in preparation; see also Alley unpublished) we will argue that this results from diagenetic mass loss from warmer snow to colder air in the autumn. The coarse-grained layer from late-summer 1983 occurs at $2 \mathrm{~m}$ and just below. We find about 15 storms per year, in agreement with the 15-16 storms per year reported by Hammer (1985) for nearby Crête.

The crusts shown are fine-grained and porous (densities $\approx 400-600 \mathrm{~kg} \mathrm{~m}^{-3}$ ). They probably form by wind action. Diagenetic changes cause most crusts to become indistinct by $2 \mathrm{~m}$ depth.

\section{Core studies}

The depth-density profile is shown in Figure 3. Pore close-off occurs at about $75-80 \mathrm{~m}$. The shallow densification has been modeled by Alley (1987). Danish and Swiss investigators collected $\mathrm{a}$ core at Site $\mathrm{A}$ at the same time and within about $200 \mathrm{~m}$ of our drilling operation, and report that the high-conductivity layer from the eruption of the volcano Laki in 1783 occurs at a depth of $81 \mathrm{~m}$ (personal communication from C.U. Hammer, 1986; Clausen and Hammer 1988, this volume). This, plus our 


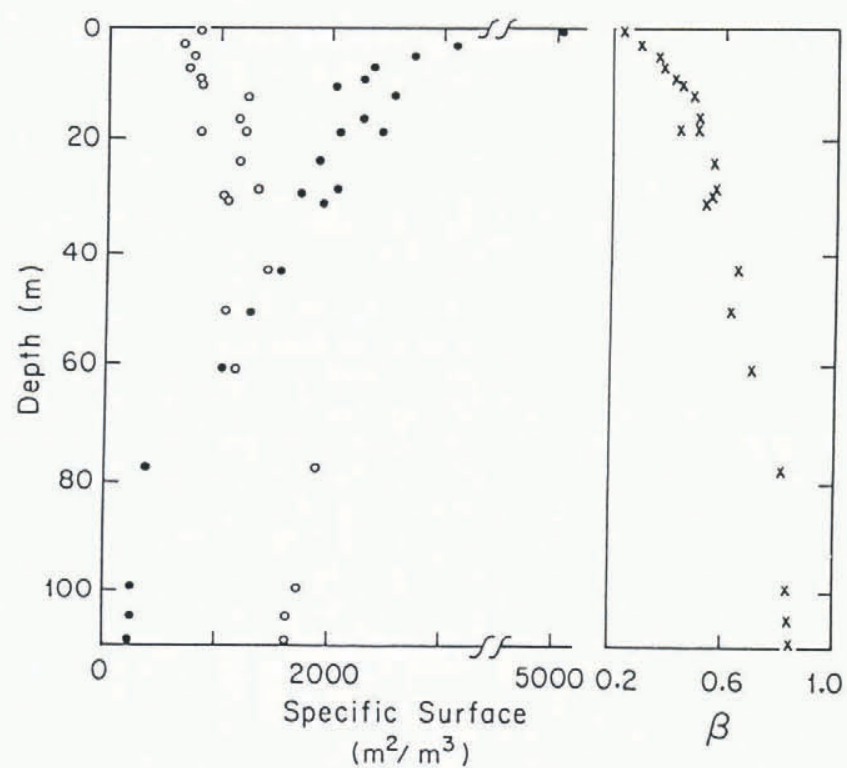

Fig.4. Surface areas versus depth. Solid circles (•) show area of ice-air surface per unit volume, open circles (o) show area of grain boundary per unit volume, and crosses ( $x$ ) show fraction, $B$, of surface area of average grain involved in grain bonds.

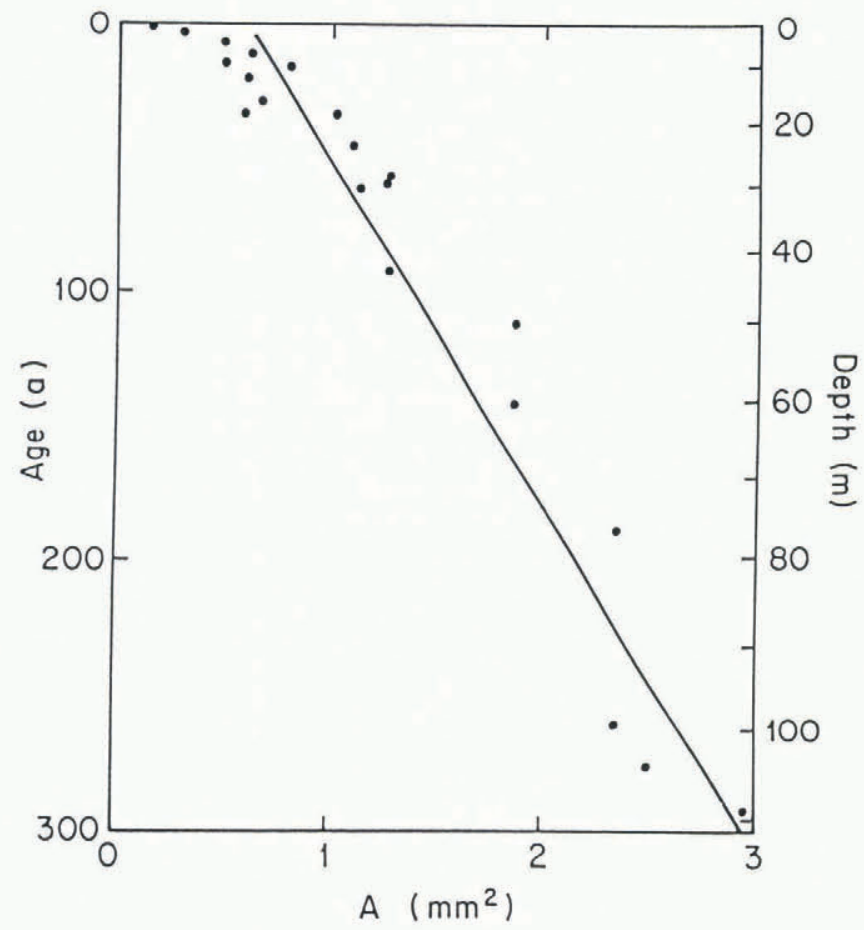

Fig.5. Grain-size, A, versus age. Grain-size was calculated as $1 \frac{1}{2}$ times the average cross-sectional area of grains exposed on a plane of section. The regression line of grain-size against age for samples from deeper than $5 \mathrm{~m}$ is shown.

depth-density curve, gives an accumulation rate of $290 \mathrm{~mm} \mathrm{a}^{-1}$ ice averaged over 202 years. (Interpretation of pit stratigraphy over the last 2 years gives a slightly higher value of about $360 \mathrm{~mm} \mathrm{a}^{-1}$ ice.)

Figure 4 shows the total areas of contact per unit volume between different grains and between grains and pores, and the fraction of the surface area of the average grain involved in grain bonds. The rapid loss of ice-air surface area in the upper $2 \mathrm{~m}$ is caused by the rapid grain growth there rig.5). Ice-air surface is then lost steadily down to pore close-off. Closing of pores prevents further

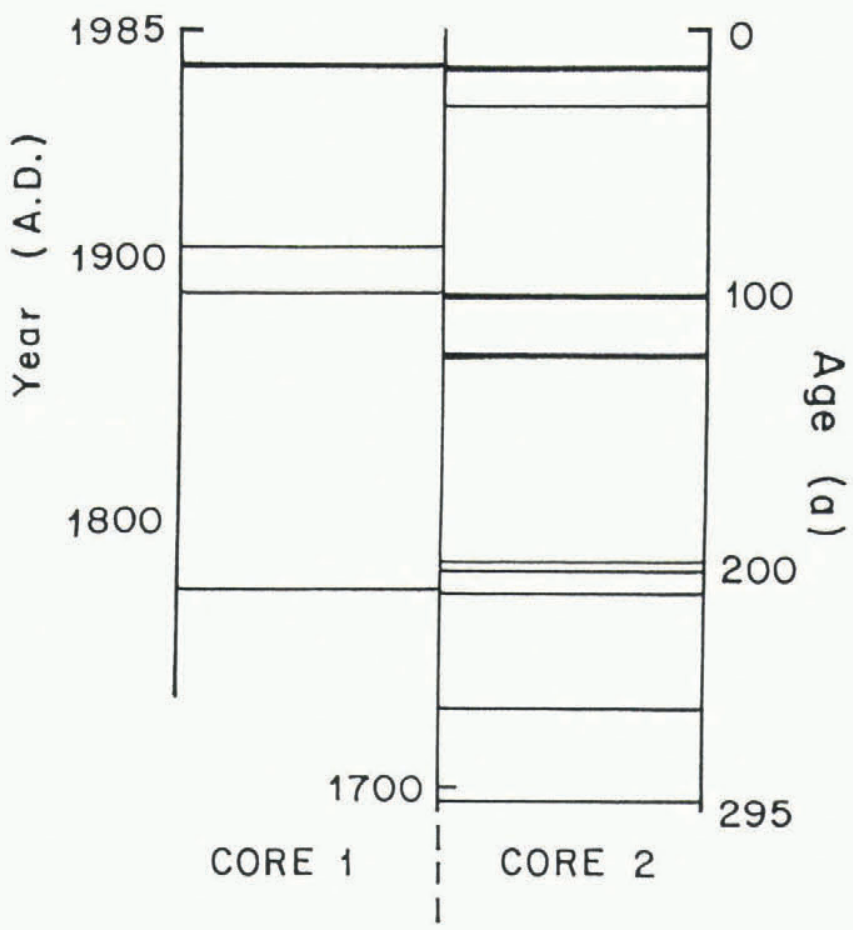

Fig.6. Melt lenses. Major events ( $\geqslant 20 \mathrm{~mm}$ ice) are shown by heavier lines.

loss of air and collapse of bubbles; thus, loss of ice-air surface is slow below pore close-off. Ice-air surface shows a vertical anisotropy in the upper $10 \mathrm{~m}$, caused by vertical vapor transport in response to meteorologic forcing; however, this anisotropy is not as strong as that observed in regions of lower accumulation, where firn spends more time at shallow depth where vertical vapor transport is significant (Alley unpublished).

Grain-size data are shown in Figure 5. We have measured the cross-sectional area of 100-200 grains on each section plane, using a computerized stereology system (Bioquant II, R. \& M. Biometrics), and averaged them

Values plotted in Figure 5 are 1.5 times this average size, a relation that is exact for mono-sized spheres and a reasonable approximation in many situations (Underwood 1970). Ages were calculated by assuming a constant accumulation rate of $290 \mathrm{~mm} \mathrm{a}^{-1}$ ice. The data below $5 \mathrm{~m}$ depth are described well by a linear dependence of grainsize on age, which gives a growth rate of $(7.8 \pm 0.5)$ $\times 10^{-3} \mathrm{~mm}^{2} \mathrm{a}^{-1}$, with an extrapolated size of $0.6 \mathrm{~mm}^{2}$ at the surface. The regression line of grain-growth rate against inverse temperature calculated by Paterson (1981, p. 19) predicts a growth rate of about $8 \times 10^{-3} \mathrm{~mm}^{2} \mathrm{a}^{-1}$ for a temperature of $-29.5^{\circ} \mathrm{C}$ (see below), in good agreement with our result.

Melt events in the cores are shown in Figure 6. About two-thirds of the events shown, including all of the major ones, are unambiguously melt events; they are lenses or glands more than a few millimeters thick, often in zones up to $70 \mathrm{~mm}$ thick. The rest of the melt events are thinner (although all are $\geqslant 2 \mathrm{~mm}$ thick) and more regular. We believe that these thinner ice layers represent the presence of liquid water on a scale larger than grain boundaries. However, we cannot eliminate the possibility that they are bonded-grain crusts formed at the ice-air surface by intense insolation, in which liquid water was restricted to grain boundaries (Langway 1967).

Core logging was conducted on the as-drilled surface. This surface was quite clean on the second core, but was irregular on the first core because of slightly poorer drill performance. It is thus unclear whether some events observed only in the second core were absent from the first or were simply not observed through the irregular core surface, although we believe that most were absent. Three of the four melt events observed in the first core also occur in the second, indicating that many melt events are 


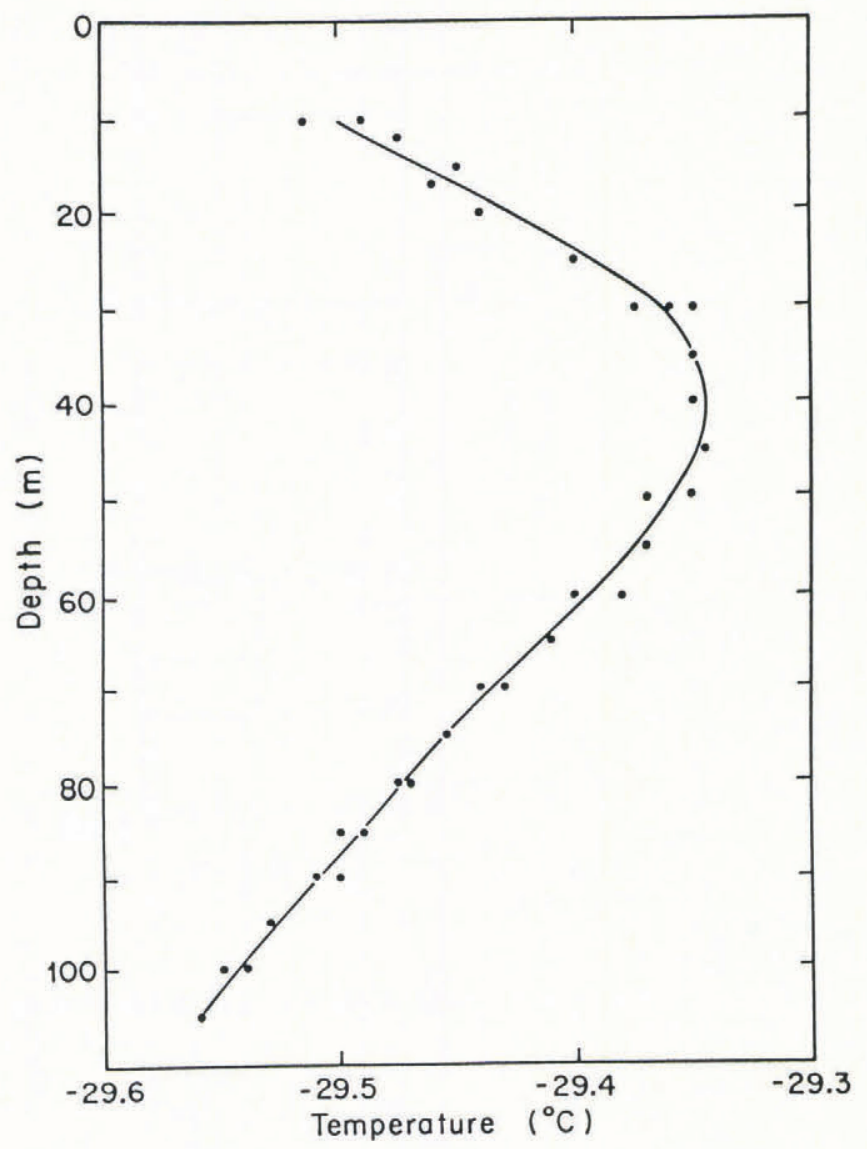

Fig.7. Depth-temperature profile. The smoothed curve was drawn by inspection.

sufficiently pervasive to allow correlation of nearby cores (see also Benson 1962 and Langway 1967). The existence of these melt events reduces the utility of Site $\mathrm{A}$ as a location for deep drilling, although the spacing of about 40 years and $10 \mathrm{~m}$ of ice between melt events is better than at most locations on the ice sheet, except at high elevations farther north (e.g. Benson 1962, Langway 1967, Langway and others 1985).

The temperature profile is given in Figure 7. Points shown were collected in the second hole on two consecutive days (after 1 and $2 \mathrm{~d}$ of equilibration) and in the first hole (after $7 \mathrm{~d}$ of equilibration), using the PICO temperature-logging system. The similarity of results from two nearby holes over varying equilibration times indicates that equilibration was good for all the surveys. The general form of the profile is similar to that from Crête (Johnsen 1977) and from other sites in central Greenland (B.L. Hansen, summarized in Robin 1983, p. 95). The $10 \mathrm{~m}$ temperature at Site $\mathrm{A}$ is about $-29.5^{\circ} \mathrm{C}$.

\section{SUMMARY}

Visible strata at Site $A$ are dominated by a storm signal. An individual storm deposits a dense, fine-grained wind slab; coarser-grained material forms by surface-hoar growth, still-air snowfall, or surficial diagenesis between storms. An annual cycle is also evident: most autumn firn is coarse-grained (this may arise from diagenetic mass loss from wind slabs). Pore close-off occurs at about $75-80 \mathrm{~m}$ depth, grains grow at a rate of about $7.8 \times 10^{-3} \mathrm{~mm}^{2} \mathrm{a}^{-1}$, the accumulation rate is about $290 \mathrm{~mm} \mathrm{a}^{-1}$ ice, and the $10 \mathrm{~m}$ temperature is about $-29.5^{\circ} \mathrm{C}$.

\section{ACKNOWLEDGEMENTS}

We thank $\mathrm{K}$ Mountain for field work and A $\mathrm{N}$ Mares and $\mathrm{S}$ H Smith for manuscript and figure preparation. This research was funded by the National Science Foundation, Division of Polar Programs, under grant DPP83-18528 to the Polar Ice Coring Office and grant DPP85-20846 to the University of Wisconsin Geophysical and Polar Research
Center. This is contribution no. 470 of the Geophysical and Polar Research Center, University of Wisconsin-Madison.

\section{REFERENCES}

Alley R B 1987 Firn densification by grain-boundary sliding: a first model. Journal de Physique 48(C1): 249-254

Alley R B Unpublished Transformations in polar firn. (PhD thesis, University of Wisconsin-Madison, 1987)

Benson C S 1962 Stratigraphic studies in the snow and firn of the Greenland ice sheet. CRREL Research Report 70

Clausen H B, Hammer C U 1988 The Laki and Tambora eruptions as revealed in Greenland ice cores from 11 locations. Annals of Glaciology 10: 16-22

Committee for Science Planning in Greenland 1985 Scientific plan for deep ice core drilling in central Greenland (GISP II). Columbus, $\mathrm{OH}$, Ohio State University Institute of Polar Studies

Daley M A, Kirby S H 1984 Thin sectioning and surface replication of ice at low temperature. Journal of Glaciology 30(105): 248-250

Hammer C U 1985 The influence on atmospheric composition of volcanic eruptions as derived from ice-core analysis. Annals of Glaciology 7: 125-129

Johnsen S J 1977 Stable isotope profiles compared with temperature profiles in firn with historical temperature records. International Association of Hydrological Sciences Publication 118 (General Assembly of Grenoble 1975 Isotopes and Impurities in Snow and Ice): 388-392

Langway C C Jr 1967 Stratigraphic analysis of a deep ice core from Greenland. CRREL Research Report 77

Langway C C Jr, Oeschger H, Dansgaard W 1985 The Greenland Ice Sheet Program in perspective. In Langway $\mathrm{C} \mathrm{C} \mathrm{Jr}$, Oeschger $\mathrm{H}$, Dansgaard $\mathrm{W}$ (eds) Greenland ice core: geophysics, geochemistry, and the environment. Washington, DC, American Geophysical Union: 1-8 (Geophysical Monograph 33)

Paterson W S B 1981 The physics of glaciers. Second edition. Oxford etc, Pergamon Press (Pergamon International Library)

Perla $R \quad 1982$ Preparation of section planes in snow specimens. Journal of Glaciology 28(98): 199-204

Robin G de Q 1983 General glaciology. In Robin G de Q (ed) The climatic record in polar ice sheets. Cambridge etc, Cambridge University Press: 94-97

Underwood E E 1970 Quantitative stereology. Reading, MA, etc, Addison-Wesley Publishing 